\title{
Greek and European consumer behaviour towards beef, lamb and mutton meat safety and quality: a review
}

\section{Anestis Tsitsos and Vangelis Economou*}

\author{
Laboratory of Hygiene of Food Animal Origin - \\ Veterinary Public Health, \\ School of Veterinary Medicine, \\ Faculty of Health Sciences, \\ Aristotle University of Thessaloniki, \\ Thessaloniki, Greece \\ Email: tsitanes@vet.auth.gr \\ Email: boikonom@vet.auth.gr \\ *Corresponding author
}

\section{Georgios Arsenos, Theodoros Kalitsis and Angeliki Argyriadou}

\author{
Laboratory of Animal Husbandry, \\ School of Veterinary Medicine, \\ Faculty of Health Sciences, \\ Aristotle University of Thessaloniki, \\ Thessaloniki, Greece \\ Email: arsenosg@vet.auth.gr \\ Email: tgkallitsis@vet.auth.gr \\ Email: argyrian@vet.auth.gr
}

\section{Alexandros Theodoridis}

Laboratory of Animal Production Economics,

Faculty of Health Sciences,

School of Veterinary Medicine,

Aristotle University of Thessaloniki,

Thessaloniki, Greece

Email: alextheod@vet.auth.gr

\begin{abstract}
Food and meat quality is formed mainly by the consumers' expectations and is related to nutritional value, organoleptic characteristics and food safety. Consumers rely on several factors that may influence their choices. Beef and sheep meat have always been considered as a highly desirable food commodity worldwide. However, the preferences in different countries and even in different social groups within the same country tend to differ. Several issues, such as contemporary health hazards and scandals, or certain socioeconomic fluctuations, can cause an abrupt change on consumer preferences. In this review an effort was made to identify the factors that influence the European consumer desires, behaviours and preferences. As a
\end{abstract}


case of interest, the Greek consumer's attitude towards different types of meat was portrayed. Therefore this review can aid food scientists and professionals in order to predict the consumer preferences and promptly adapt to any changes observed.

Keywords: consumer; behaviour; preferences; lamb meat; beef; Europe; Greece.

Reference to this paper should be made as follows: Tsitsos, A., Economou, V., Arsenos, G., Kalitsis, T., Argyriadou, A. and Theodoridis, A. (2021) 'Greek and European consumer behaviour towards beef, lamb and mutton meat safety and quality: a review', Int. J. Agricultural Resources, Governance and Ecology, Vol. 17, Nos. 2/3/4, pp.414-431.

Biographical notes: Anestis Tsitsos graduated from the School of Veterinary Medicine, Aristotle University of Thessaloniki (Greece) with distinction. He is currently a PhD candidate in Food Hygiene and Veterinary Public Health and a resident of the European College of Veterinary Public Health. His scientific interests include veterinary medicine, food hygiene, food microbiology and antimicrobial resistance. He has taken part in scientific projects and activities in Greece and Cyprus. He has also participated in national and international conferences and workshops.

Vangelis Economou holds a tenured position of Assistant Professor at the Department of Hygiene and Technology of Food of Animal Origin, School of Veterinary Medicine, Aristotle University of Thessaloniki, Greece. His current research interests involve meat and seafood hygiene with an emphasis on the control of foodborne pathogens and the emergence of antimicrobial resistance. He has published over 40 papers in national and international peer-reviewed journals with more than 800 citations and has over 70 presentations in scientific conferences. He has been a reviewer for several national and international research projects and for more than 40 international scientific journals.

Georgios Arsenos has over 25 years of experience in animal science research and education. His scientific expertise includes veterinary medicine, animal husbandry, data analysis and sustainability of livestock production systems. $\mathrm{He}$ held research and academic positions in the UK and Greece leading several national, industry and EU-funded research projects (104 research projects). His highlights of service outside the university include numerous seminars for vet practitioners, farmers, as well as consultancy to individual farms, farm cooperatives and dairies. He has authored one book and co-authored two books, and 113 refereed papers (1274 citations, h-index: 22). He has participated in numerous national and international conferences.

Theodoros Kalitsis holds a PhD in Food Science/Food Microbiology and MSc in Food Science/Food Process - Engineering, both from the University of California at Davis. He is a veterinarian by training at the Aristotle University of Thessaloniki. He has worked as a senior food scientist in the private sector. He has been managing projects in new product development and new activities related to food. His particular interests focus in food product development and problem solving in production and preservation of foods and he is trained as food communication expert.

Angeliki Argyriadou graduated from the School of Veterinary Medicine, Faculty of Health Sciences of the Aristotle University of Thessaloniki in 2014. During her post-graduate traineeship, she acquired a broad experience in ruminant husbandry practices. She is currently a $\mathrm{PhD}$ student investigating the 
genetics of performance resilience under heat stress conditions in local dairy sheep breeds. She has also been involved in three research projects on ruminant meat quality and breeding for efficiency and resilience. She has presented her research in national and international conferences and peer-reviewed journals.

Alexandros Theodoridis is an Associate Professor in Animal Production Economics and Applied Statistics, at the School of Veterinary Medicine, Aristotle University of Thessaloniki (AUTH), Greece. He has participated in 25 scientific projects and has more than 80 papers in peer-reviewed journals and conference proceedings (Scopus: 538 citations, h-index: 13). His main research interests include economics of agricultural and animal production, agricultural policy and sustainable rural development and statistical analysis of experimental and survey data.

This paper is a revised and expanded version of a paper entitled 'A review of consumer preferences for lamb and beef products' presented at the 9th International Conference on Information and Communication Technologies in Agriculture, Food \& Environment, Thessaloniki, Greece, 24-27 September 2020.

\section{Introduction}

Consumer opinion on the quality of meat can be quite complex (Pethick et al., 2011). Food quality is characterised by its degree of adaptation to consumers' requirement which are related to nutritional value, organoleptic characteristics and food safety (Bremner, 2000; Petrescu et al., 2020). Consumers rely on conscious or subconscious factors that may influence their choices. These factors are distinguished into endogenous and exogenous. Endogenous factors are the organoleptic characteristics of the food, its nutritional value and its safety. They are characteristics of the product that cannot be changed unless the nature of the product changes, and are particularly important in assessing the quality of meat and meat products. Still, they can often mislead the consumer to form a false view of the quality of a product (Guenther et al., 2005). Exogenous factors are individual or environmental factors that, even though they are not property of food, they do provide information about it and may be altered due to external factors. Endogenous factors are directly related to food quality, while exogenous factors include psychological factors, sociocultural factors and marketing (Grunert et al., 2004; Font-i-Furnols and Guerrero, 2014). These factors are interrelated and can affect both people's cognitive and emotional intelligence (Figure 1).

Beef and sheep meat have always been high in consumer preferences worldwide. However, there are many differences observed both within and among countries regarding which type of meat is preferred and considered of better quality. For example, according to Henchion et al. (2017), the most important factors that influence consumer beef preferences are price, quality labelling, fat content, taste and freshness. On the other hand, Aboah and Lees (2020) state that the five most important quality characteristics that consumers utilise in their purchasing decisions are food safety certification, price, country of origin, production system and quality certification labels, all of which are extrinsic factors and relate to credence attributes. Still the definition of each of these parameters can vary widely among consumers, with the desired trait being quite 
subjective, even among specific areas. Thus, the mapping of consumer behaviour is quite demanding, especially for beef and ovine meat, due to the concerns about health issues and environmental sustainability that are related to them and due to the shift of meat consumption from red meats to poultry and pork (Mandolesi et al., 2020; Dudinskaya et al., 2021). Moreover, food scandals, such as the crisis of bovine spongiform encephalopathy in the 1990s, can cause abrupt changes in consumer preferences (Rezitis and Stavropoulos, 2012). It is therefore vital for the beef and ovine market to be able to interpret the factors influencing consumer behaviour towards beef, lamb and mutton, in order to promptly adapt to any changes observed. The scope of this review is to identify the factors that may influence consumer desires, behaviours and preferences.

Figure 1 Factors that influence consumers' behaviour and preferences

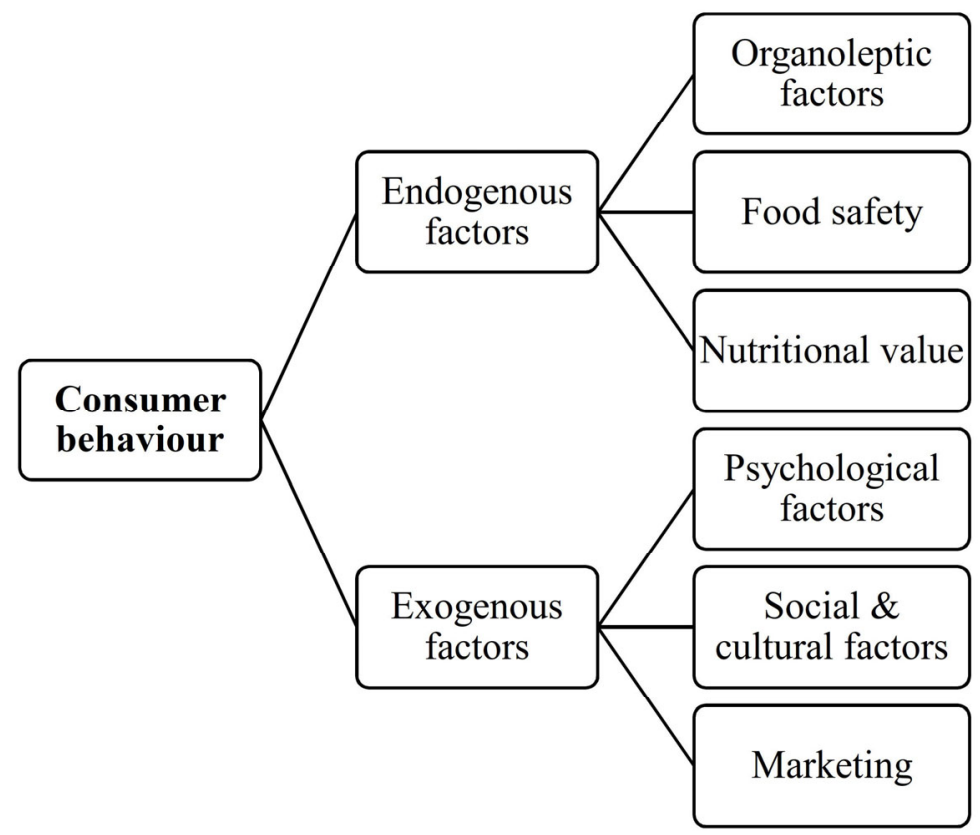

\section{Factors that shape consumer behaviour and preferences towards beef and sheep meat}

\subsection{Endogenous factors}

Meat and meat products are food commodities with high nutritional value and excellent organoleptic properties. They contain proteins of animal origin of high biological value, fats, essential minerals and vitamins in high concentrations, and carbohydrates in small quantities. Meat is an almost-complete food, as its chemical composition resembles that of the human body and thus, a proper amount of meat is necessary to be included in the human diet (McNeill and van Elswyk, 2012). However, the overconsumption of meat and processed meat products may lead to cardiovascular diseases, obesity, type 2 diabetes and 
certain types of cancers (especially colorectal cancer) (Ardisson Korat et al., 2014; Boutron-Ruault et al., 2017; Mijatovic-Vukas et al., 2018; Toi et al., 2020; George et al., 2021; Vernia et al., 2021; Michel et al., 2021). Moreover, biological (such as bovine spongiform encephalopathy, avian influenza or salmonellosis), chemical (such as microbial toxins, dioxins and dioxin-like polychlorinated biphenyls), and physical hazards in meat and meat products, have raised consumers' concerns about the risks and benefits of meat consumption (Font-i-Furnols and Guerrero, 2014; Koutsoumanis et al., 2020). However, healthiness and nutritional value of meat appear to be more significant to consumers than safety, which is often regarded as a perquisite (van Rijswijk and Frewer, 2008; Verbeke et al., 2010; Petrescu et al., 2020). Health seems to be an important reason for changing consumption habits and thus, an important percentage of consumers reduce or even eliminate meat from their diet (Latvala et al., 2012; Cheah et al., 2020). Nutritional awareness concerning meat products may alter consumer preferences, especially for specific types of meat (Guenther et al., 2005; Zeng et al., 2019). For example, there is a positive attitude towards beef or sheep meat products with reduced fat or salt (Guàrdia et al., 2006; Kumar, 2019; López-Pedrouso et al., 2021; Paglarini et al., 2020), even though a significant portion of consumers are not ready to exchange inferior organoleptic properties for health benefits (Verbeke and Ward, 2006). In any case, adequate meat labelling could improve public confidence in these products, especially for the consumers who are concerned about nutritional value and food safety (Font-i-Furnols and Guerrero, 2014).

Organoleptic parameters play a significant role in consumer preferences, with the most important factors regarding beef and sheep meat being appearance, colour, taste, aroma, juiciness and tenderness of meat. These factors are influenced by both endogenous and exogenous factors, such as animal species, breed, nutrition, age, animal's welfare conditions during slaughter, ante mortem treatment of the animal and post mortem treatment of the carcass, maintenance and maturation of meat (Pethick et al., 2005; Font-i-Furnols and Guerrero, 2014; Massaglia et al., 2018). Thus, it is quite difficult to improve one organoleptic characteristic of a meat product without adversely affecting another. Organoleptic factors and particularly appearance and taste, influence consumers' preferences regarding beef and ovine meat. Meat colour is considered to be one of the most important fresh meat characteristics, as most people correlate specific colour to meat spoilage or wholesomeness (Font-i-Furnols and Guerrero, 2014). Bright red is the most preferred colour and an indicator of fresh meat, whereas brown is the least preferred and an indicator of spoilage (Carpenter et al., 2001; Feuz et al., 2020). Consumers' preferences towards fat are heterogeneous, meaning that it is hard to decipher the role of fat in willingness to pay (Dudinskaya et al., 2021). More consumers prefer to buy leaner meat cuts and products, as the consumption of a large amount of fat is considered unhealthy (Ngapo and Dransfield, 2006; Dudinskaya et al., 2021). Tenderness, juiciness, taste and aroma are also highly correlated with consumers' purchasing decisions and willingness to pay (Banović et al., 2009; Silvestri et al., 2020). These characteristics are positively correlated with the intramuscular fat content and the type of fat (Pannier et al., 2014). Furthermore, meat's aroma is influenced by animal species. Lamb and mutton is differentiated from beef due to the formers' intense aroma, a characteristic which is not widely acceptable among consumers (Matsuishi et al., 2004; Maughan and Martini, 2012). In addition, many differences are observed both within and among countries, regarding consumer preferences for the desirable organoleptic characteristics of meat. For example, marbling content is generally preferred in Asian 
countries (Ngapo et al., 2007), whereas in other countries it is negatively affecting meat appearance and consumer preferences (Moeller et al., 2010). In a recent survey among Brazilian and Spanish consumers, Boito et al. (2021) report that beef marbling was sought for, since consumers are correlating it with increased tenderness. Moreover, some consumers show preference for lamb which is fed with milk or concentrate and has lower weight and lighter meat coloration, while other countries prefer mutton over lamb, which has darker coloration, is produced from heavier sheep reared in pastures that are slaughtered at an older age (Bernués et al., 2012). Familiarity, customs and habits of consumption are important factors concerning the formation of the final consumer preferences (Leroy and Praet, 2015).

\subsection{Exogenous factors}

The impact of psychological, social and cultural traits on consumer behaviour has always concerned the scientific community. Factors such as common beliefs, attitudes, expectations, motivations, perceptions, lifestyles and values shape consumer personalities and influence their behaviour (Font-i-Furnols and Guerrero, 2014). In general, consumers tend to follow the already established behaviour towards meat (Povey et al., 2001). Thus, consumer attitudes and perceptions towards meat and its products depend both on the characteristics of the product and on the already established behaviour. However, meat tends to have a rather negative image in the general public on average, due to factors related to animal welfare, slaughter conditions (Troy and Kerry, 2010), the environment (Povey et al., 2001), religion, ideology and ethics (Berndsen and van der Pligt, 2005). In addition, risks concerning meat safety, such as bovine spongiform encephalopathy, and the potentially adverse effect of meat consumption on human health, are important reasons for the consumers to change their eating habits by reducing or even eliminating meat from their diet (Garnier et al., 2003; Latvala et al., 2012; Clonan et al., 2015). However, these negative attitudes do not seem to have a significant effect on meat market (Grunert, 2006; Font-i-Furnols and Guerrero, 2014), as consumers prefer to change the role assigned to meat within a meal instead of reducing meat consumption. Meat is now treated as an ingredient, rather than the most highly valued and important part of the meal (Font-i-Furnols and Guerrero, 2014; Faber et al., 2020). The value consumers attribute to meat is also indicated by the fact that even vegetarian dishes include plant derived food prepared as if they were meat and appear similar to meat dishes (Font-i-Furnols and Guerrero, 2014; Holm and Møhl, 2000). This consumer behaviour can be interpreted by two main psychological mechanisms: selective amnesia, which degrades unpleasant memories consciously or subconsciously (Font-i-Furnols and Guerrero, 2014), and cognitive dissonance, in which any discrepancy observed between consumer expectations and product performance will be assimilated by consumers, who will change their perceptions of the product to conform more to their expectations (Deliza and MacFie, 1996; Dickinson and Kakoschke, 2021).

Consumers receive much of the information regarding meat through advertisements, campaigns or quality labelling. This information is capable of creating expectations for a product and thus affecting intention to purchase and willingness to pay. Several marketing strategies have been adopted, such as online shopping and telemarketing, in order to increase sales and business revenues and to influence consumer behaviour and preferences (Font-i-Furnols and Guerrero, 2014). The most important marketing 
parameters that have an influence on consumer preferences are the price of the product and its quality labelling. Price is an extrinsic factor which is directly related to the demographic characteristics of a country, since low-income consumers prefer low quality cuts (Reicks et al., 2011; Yang et al., 2021). Although high price is often associated with high food quality (Acebrón and Dopico, 2000), lower prices are often preferred, especially for consumers with low purchasing power, who occasionally eat meat or do not show interest in the type of meat they consume, replacing an expensive meat product with a more affordable one (Font-i-Furnols and Guerrero, 2014; Yang et al., 2021). As far as quality labelling is concerned, the most common information sought by consumers is the product's brand/name, expiration date, quantity statements and country of origin (Verbeke and Ward, 2006). Certified product brands and domestic products are preferred by consumers, as they relate them to freshness, tastiness and high quality and safety (Chambers et al., 2007; Feldmann and Hamm, 2015). Muslim consumers pay significant attention to certified halal meat, which assures that food is prepared in a halal way and guarantees halal authenticity of meat and meat wholesomeness (Hossain et al., 2020; Bhatti et al., 2021; Dudinskaya et al., 2021). Young and more acclimated female Muslims are willing to pay more for halal beef (Verbeke et al., 2013; Hossain et al., 2020). Moreover, organic products are highly preferred by consumers, even though they are more expensive due to their pricey production (Kim et al., 2008; Capuano et al., 2013; de Jonge and van Trijp, 2013). Consumers are willing to pay more for a certified organic product, mainly because organic production is safe for the environment and guarantees nutrition, better ecological footprint, ethics and high food quality and safety (Verbeke et al., 2010; Dudinskaya et al., 2021). However, many differences are observed regarding consumer preferences worldwide, making it more difficult for their behaviour to be deciphered (Table 1).

Table 1 Summary of the factors and parameters that shape consumers' behaviour and preferences

\begin{tabular}{|c|c|c|c|c|c|}
\hline \multicolumn{3}{|c|}{ Endogenous factors } & \multicolumn{3}{|c|}{ Exogenous factors } \\
\hline $\begin{array}{l}\text { Organoleptic } \\
\text { factors }\end{array}$ & Food safety & $\begin{array}{c}\text { Nutritional } \\
\text { value }\end{array}$ & $\begin{array}{l}\text { Psychological } \\
\text { factors }\end{array}$ & $\begin{array}{c}\text { Social and } \\
\text { cultural factors }\end{array}$ & Marketing \\
\hline \multirow{7}{*}{$\begin{array}{l}\text { Appearance } \\
\text { Colour } \\
\text { Taste } \\
\text { Flavour } \\
\text { Juiciness } \\
\text { Tenderness }\end{array}$} & \multirow{7}{*}{$\begin{array}{l}\text { Microbiological } \\
\text { hazards } \\
\text { Chemical } \\
\text { hazards } \\
\text { Physical hazards }\end{array}$} & Energy & Beliefs & \multirow{7}{*}{$\begin{array}{c}\text { Religion } \\
\text { Demographics } \\
\text { Origin } \\
\text { Income } \\
\text { Lifestyle }\end{array}$} & Price \\
\hline & & Fat & Attitudes & & Quality \\
\hline & & Protein & Expectations & & labelling \\
\hline & & Carbohydrates & & & Adverts \\
\hline & & Minerals & Perceptions & & Campaigns \\
\hline & & Vitamins & Values & & Telemarketing \\
\hline & & & & & $\begin{array}{l}\text { Online } \\
\text { shopping }\end{array}$ \\
\hline
\end{tabular}

\section{Beef, lamb and mutton consumption trends in Europe}

Consumer preferences concerning beef may vary both within and among European countries (Table 2). In Italy, the five most important factors are the price of the product, animal welfare, animal breed, the labelling of the product and whether the food is organic (Merlino et al., 2018). On the other hand, the factors that affect Italian consumers the 
least are the organoleptic characteristics of a beef product other than taste (e.g., tenderness, aroma, colour), its origin, nutritional value and the existence of an identification and traceability system. Nevertheless, Scozzafava et al. (2016) note that there are two significant portions of Italians: the first portion gives importance to beef cuts, purchasing specific cuts and types of beef (e.g., cutlet, steak, minced meat), and being unlikely to switch to different cuts even if the price is reduced, while the other pays more attention to the origin of a beef product and its nutritional characteristics and it is prone to switch between different cuts depending on price and availability. Similar categories of citizens are mentioned by Mesías et al. (2005) for Spain, highlighting that the origin of beef, its labelling, production process and price, are the main factors that affect Spanish preferences. German consumers also show a significant preference for quality labelled products, especially black Angus meat, for which they are willing to pay more than other types of beef (Meyerding et al., 2018).

Other differences regarding consumer behaviour among European countries are described by Almli et al. (2013), in the example of Belgium and Norway. In both countries there is a clear preference for beef tenderloin. Still Norwegians are not willing to buy it because of its high price, in contrast to Belgium, where its price is comparatively lower, indicating that price and marketing in general may affect consumer preferences. Moreover, Norwegians show higher hedonic involvement with beef and pay less attention to nutritional value, food safety and technology, diametrically opposed to Belgians' preferences. In general, European consumers consider a reasonable consumption of beef beneficial to their health, thus positively affecting beef purchase. Their preferences are towards leaner (Ngapo and Dransfield, 2006; van Wezemael et al., 2014), local (Realini et al., 2013; Miller, 2020; Stampa et al., 2020) and less technologically processed beef (Verbeke et al., 2010).

Many differences occur in consumer preferences among countries regarding highquality sheep meat (Table 2). The most significant difference is related to the preference of consumers of the Mediterranean countries and Northern Europe for lamb and mutton respectively. The former prefer carcasses of light weight and lambs fed with milk or concentrate, while the latter prefer carcasses of heavier weight and grass-fed sheep. Consumers in France, the UK and Iceland prefer French or Icelandic sheep breeds, which produce carcasses over $15 \mathrm{~kg}$, while in Spain and Italy they prefer autochthonous sheep breeds, with a carcass of less than $10 \mathrm{~kg}$ (Sañudo et al., 2007). The factors mainly influencing European consumers' choices are the origin and type (lamb or mutton) of meat, and the animal's breeding system (Font-i-Furnols et al., 2011). The less important factors include price (Bernabéu and Tendero, 2005), specific cuts, nutritional value, labelling, expiration date and traceability (Bernués et al., 2003). However, each of the above factors does not have the same impact on all consumers. Bernués et al. (2003) state that some consumers are mostly affected by food quality and safety, others pay more attention to the ease of cooking or the origin of the food product, whereas some consumers are more conservative and are mainly influenced by its appearance and organoleptic characteristics. Moreover, Gracia and De-Magistris (2013) support that, although the origin and type of ovine meat play a significant role in consumer behaviour, the majority of Spanish consumers would not pay more to buy ovine meat that satisfies their requirements and desires. Instead, they would settle for a cheaper product even if that falls short of expectations. In general, European consumers prefer to purchase 
domestic and fresh lamb or mutton, indicated by its bright red colour and its white-coloured fat (Bernués et al., 2012).

Table 2 Meat preferences studies among European consumers.

\begin{tabular}{|c|c|c|c|c|c|}
\hline Reference & Country & $\begin{array}{l}\text { Sample } \\
\text { size }\end{array}$ & Method & Meat type & $\begin{array}{l}\text { Most important } \\
\text { factors }\end{array}$ \\
\hline $\begin{array}{l}\text { Bernués et al. } \\
\text { (2003) }\end{array}$ & $\begin{array}{l}\text { England, France, } \\
\text { Italy, Scotland, } \\
\text { Spain }\end{array}$ & 2,288 & Focus groups & $\begin{array}{l}\text { Beef, } \\
\text { sheep }\end{array}$ & $\begin{array}{l}\text { Expiration date, } \\
\text { origin, traceability, } \\
\text { cuts, nutritional } \\
\text { value, safety }\end{array}$ \\
\hline $\begin{array}{l}\text { Bernabéu and } \\
\text { Tendero }(2005)\end{array}$ & Spain & 400 & Questionnaire & Sheep & $\begin{array}{c}\text { Cuts, origin, price, } \\
\text { labelling }\end{array}$ \\
\hline $\begin{array}{l}\text { Mesías et al. } \\
(2005)\end{array}$ & Spain & 575 & $\begin{array}{l}\text { Personal } \\
\text { interviews }\end{array}$ & Beef & $\begin{array}{l}\text { Origin, labelling, } \\
\text { breeding system, } \\
\text { price }\end{array}$ \\
\hline $\begin{array}{l}\text { Ngapo and } \\
\text { Dransfield (2006) }\end{array}$ & UK & 1,064 & Questionnaire & Beef & Cuts, fat content \\
\hline $\begin{array}{l}\text { Verbeke et al. } \\
\text { (2010) }\end{array}$ & $\begin{array}{l}\text { Germany, Spain, } \\
\text { France, UK }\end{array}$ & 65 & $\begin{array}{l}\text { Focus groups, } \\
\text { online survey }\end{array}$ & Beef & $\begin{array}{l}\text { Technologically } \\
\text { processed products }\end{array}$ \\
\hline $\begin{array}{l}\text { Font-i-Furnols } \\
\text { et al. (2011) }\end{array}$ & $\begin{array}{l}\text { Spain, France, } \\
\text { UK }\end{array}$ & 291 & Questionnaire & Sheep & $\begin{array}{l}\text { Origin, price, } \\
\text { animal nutrition }\end{array}$ \\
\hline $\begin{array}{l}\text { Bernués et al. } \\
\text { (2012) }\end{array}$ & Spain & 343 & Questionnaire & Sheep & $\begin{array}{c}\text { Origin, freshness, } \\
\text { colour, fat content, } \\
\text { labelling, animal } \\
\text { nutrition }\end{array}$ \\
\hline Almli et al. (2013) & $\begin{array}{l}\text { Norway, } \\
\text { Belgium }\end{array}$ & 218 & Questionnaire & Beef & $\begin{array}{l}\text { Price, nutritional } \\
\text { value, safety, cuts }\end{array}$ \\
\hline $\begin{array}{l}\text { Gracia and } \\
\text { De-Magistris } \\
(2013)\end{array}$ & Spain & 266 & Questionnaire & Sheep & $\begin{array}{c}\text { Origin, social } \\
\text { factors, price, fat } \\
\text { content, freshness, } \\
\text { colour }\end{array}$ \\
\hline $\begin{array}{l}\text { Scozzafava et al. } \\
(2016)\end{array}$ & Italy & 1,500 & Online survey & Beef & $\begin{array}{l}\text { Cuts, origin, } \\
\text { organic product, } \\
\text { safety }\end{array}$ \\
\hline $\begin{array}{l}\text { Merlino et al. } \\
(2018)\end{array}$ & Italy & 401 & Questionnaire & Beef & $\begin{array}{c}\text { Price, animal breed } \\
\text { and welfare, } \\
\text { labelling }\end{array}$ \\
\hline $\begin{array}{l}\text { Meyerding et al. } \\
(2018)\end{array}$ & Germany & 55 & $\begin{array}{l}\text { Sensory tests, } \\
\text { willingness to } \\
\text { pay }\end{array}$ & Beef & $\begin{array}{c}\text { Flavour, taste, } \\
\text { tenderness, } \\
\text { juiciness, labelling, } \\
\text { price, origin, meat } \\
\text { type }\end{array}$ \\
\hline Ripoll et al. (2018) & Spain & 200 & Online survey & Sheep & $\begin{array}{l}\text { Origin, fat content, } \\
\text { labelling, freshness, } \\
\text { organic product }\end{array}$ \\
\hline $\begin{array}{l}\text { Mandolesi et al. } \\
(2020)\end{array}$ & $\begin{array}{c}\text { Finland, France, } \\
\text { Greece, Italy, } \\
\text { Spain, Turkey, } \\
\text { UK }\end{array}$ & 140 & Focus groups & $\begin{array}{l}\text { Sheep and } \\
\text { goat }\end{array}$ & $\begin{array}{c}\text { Unique taste, } \\
\text { authenticity and } \\
\text { natural production, } \\
\text { health and } \\
\text { enjoyment of life }\end{array}$ \\
\hline
\end{tabular}


It is evident that there are differences in meat preferences among European consumers that may also change abruptly when a food crisis occurs. These differences and the consumer reaction can be explained partially by individual or group characteristics present in different areas. An interesting categorisation regarding sheep meat preferences was reported by Ripoll et al. (2018) who have categorised Spanish meat consumers in four main categories: gourmet, conservative, basic and disinterested. Gourmet consumers are fond of ovine meat, use new recipes and are more likely to purchase innovative sheep products and cuts. Conservative consumers include sheep meat as part of their diet, but prefer traditional recipes and do not easily accept new products. Basic consumers are not stable concerning their tendency towards ovine meat and they consume it only occasionally, whereas disinterested consumers dislike sheep meat and avoid its consumption.

\section{Consumer preferences regarding beef and sheep meat within a country: the example of Greece}

In Greece, the average annual meat consumption is lower than the European average, mainly due to climatic and environmental factors and the dominance of the Mediterranean diet on the Greek cuisine. Meat consumption in Greece increased substantially during the 1970s and 1980s, stabilising from the 1990s onwards. According to the most recent available data published in FAO database (FAOSTAT, 2021), in 2013 the annual per capita consumption in Greece was $16.1 \mathrm{~kg}$ of bovine meat and $12.47 \mathrm{~kg}$ of lamb/mutton and kid/goat meat. Greek consumers prefer to buy meat from local butcher shops or supermarkets (Krystallis et al., 2006). According to Dudinskaya et al. (2021), the most preferred beef and lamb cuts by Greeks, based on the results of a discrete choice experiment, are beef T-bone and lamb chops. However, the relevant literature on meat consumption in Greece is limited and little information is available regarding the preferred cuts of beef and sheep meat (Table 3).

Greek cattle husbandry mainly consists of a large number of local, small farms, although recently a noticeable increase in the establishment of large dairy farms has been observed. Nevertheless, the small size of the farms and the lack of the necessary technical knowledge acquired by producers do not affect the preferences of Greek consumers for beef (Krystallis et al., 2006). Domestic production does not cover the amount of beef consumed in Greece (FAOSTAT, 2021). In fact, beef imports exceed the imports of all types of meat. During the 1990s, when the universal beef industry went through a food crisis due to the bovine spongiform encephalopathy (BSE), beef production in Greece and the price of beef were not particularly affected, as there was only one official report of BSE beef by Greek authorities in 2001 (Rezitis and Stavropoulos, 2012). According to the studies available, the most important factor regarding purchasing behaviour in Greek beef market is taste, an attribute that can be assessed only after purchasing. Therefore consumers rely on a variety of characteristics that can be assessed during purchase, such as appearance, colour and fat content (Krystallis et al., 2006). Social factors are also affecting Greek consumer behaviour, such as the age of the consumers and their educational level. Older people and people with lower educational level appear to choose beef based only on product labelling, in contrast to younger and more educated consumers who further explore nutritional value and microbial safety (Krystallis and 
Arvanitoyannis, 2006). According to Morrison et al. (2003), exogenous factors can potentially affect the Greek market. However, the prices of beef have been relatively stable; therefore, its purchase is mainly influenced by consumer's income, with older people being more affected (Krystallis and Arvanitoyannis, 2006). The financial crisis in Greece and the volatile economic environment in general have had an impact on the purchasing behaviour of consumers in Greece who moved to low-priced meat cuts and products.

Table 3 Meat preferences studies among Greek consumers

\begin{tabular}{|c|c|c|c|c|c|}
\hline Reference & Country & Sample size & Method & $\begin{array}{l}\text { Meat } \\
\text { type }\end{array}$ & $\begin{array}{l}\text { Most important } \\
\text { factors }\end{array}$ \\
\hline $\begin{array}{l}\text { Morrison et al. } \\
\text { (2003) }\end{array}$ & Greece & - & Review & $\begin{array}{l}\text { Beef, } \\
\text { lamb }\end{array}$ & $\begin{array}{l}\text { Price, income, } \\
\text { taste }\end{array}$ \\
\hline $\begin{array}{l}\text { Krystallis and } \\
\text { Arvanitoyannis } \\
\text { (2006) }\end{array}$ & Greece & 268 households & $\begin{array}{c}\text { Questionnaire, } \\
\text { personal } \\
\text { interview }\end{array}$ & $\begin{array}{l}\text { Beef, } \\
\text { lamb }\end{array}$ & $\begin{array}{c}\text { Safety, } \\
\text { nutritional value, } \\
\text { labelling, taste, } \\
\text { appearance }\end{array}$ \\
\hline $\begin{array}{l}\text { Krystallis et al. } \\
(2006)\end{array}$ & Greece & 268 households & $\begin{array}{c}\text { Questionnaire, } \\
\text { personal } \\
\text { interview }\end{array}$ & $\begin{array}{l}\text { Beef, } \\
\text { lamb }\end{array}$ & $\begin{array}{l}\text { Organic product, } \\
\text { price, availability }\end{array}$ \\
\hline $\begin{array}{l}\text { Sañudo et al. } \\
\text { (2007) }\end{array}$ & $\begin{array}{l}\text { Greece, Spain, } \\
\text { Italy, France, } \\
\text { UK, Iceland }\end{array}$ & 773 & $\begin{array}{c}\text { Organoleptic } \\
\text { evaluation at } \\
\text { home, } \\
\text { questionnaire }\end{array}$ & Lamb & $\begin{array}{l}\text { Smell, aroma, } \\
\text { tenderness, } \\
\text { juiciness, flavour }\end{array}$ \\
\hline $\begin{array}{l}\text { Mandolesi et al. } \\
(2020)\end{array}$ & $\begin{array}{c}\text { Finland, } \\
\text { France, Greece, } \\
\text { Italy, Spain, } \\
\text { Turkey, UK }\end{array}$ & 140 & Focus groups & $\begin{array}{l}\text { Sheep } \\
\text { and goat }\end{array}$ & $\begin{array}{l}\text { Unique taste, } \\
\text { authenticity and } \\
\text { natural } \\
\text { production, } \\
\text { health and } \\
\text { enjoyment of life }\end{array}$ \\
\hline $\begin{array}{l}\text { Dudinskaya } \\
\text { et al. (2021) }\end{array}$ & $\begin{array}{c}\text { Finland, } \\
\text { France, Greece, } \\
\text { Italy, Spain, } \\
\text { Turkey, United } \\
\text { Kingdom }\end{array}$ & 2,900 & $\begin{array}{l}\text { Discrete choice } \\
\text { experiment }\end{array}$ & $\begin{array}{l}\text { Beef, } \\
\text { sheep, } \\
\text { goat }\end{array}$ & $\begin{array}{l}\text { Price, origin, } \\
\text { organic labelling, } \\
\text { carbon footprint } \\
\text { labelling, halal } \\
\text { labelling, protein } \\
\text { content labelling, } \\
\text { fat content, } \\
\text { convenience }\end{array}$ \\
\hline
\end{tabular}

Sheep breeding is a traditional field of Greek animal husbandry, consisting mainly of numerous small farms (Mandolesi et al., 2020; Dudinskaya et al., 2021). Despite the several problems, Greece has high self-sufficiency regarding sheep meat, since its domestic production covers up to $90 \%$ of its consumption (Krystallis et al., 2006; Rezitis and Stavropoulos, 2012; FAOSTAT, 2021). Greeks prefer to eat lamb over mutton, as it is considered to be of better quality due to its lighter coloration (Bernabéu and Tendero, 2005). Lambs are usually slaughtered at the age of 4-8 weeks, producing a carcass weight that varies between 6-10 kg (Christodoulou et al., 2007). However, in specific regions of the country (Epirus, Sterea Ellada) a significant portion of citizens, especially in the countryside, consume heavier sheep carcasses (over $13 \mathrm{~kg}$ ) (Skapetas et al., 2006). Skapetas et al. (2006) argue that the heaviest sheep carcass is more acceptable to Greek consumers when they are informed about its high nutritional value. Both lamb and 
mutton consumption present seasonal demand, with Easter being the period of the highest demand due to religious purposes (Mandolesi et al., 2020). Sañudo et al. (2007) examined consumer preferences in six European countries. After organoleptic examination of meat of different breeds at different ages of slaughter, they concluded that taste (juiciness, tenderness, and aroma) and appearance (colour, fat content) play the most important role in beef and lamb meat selections. These factors are mainly influenced by the animal's breed, age and diet. Most Greek consumers prefer to consume autochthonous sheep breeds with a slaughter age of up to 2.5 months. Similarly to beef, there are limited literature sources describing the preferred sheep meat cuts. In general, small cuts are preferred (e.g., chops, ribs, leg), because they are considered easier to prepare and cook (Mandolesi et al., 2020; Dudinskaya et al., 2021). The sheep and goat carcasses are usually cut shortly before they are sold in the butcher's shop and their cuts follow those of cattle (Mandolesi et al., 2020) (Table 4).

Table 4 Greek cuts of bovine and sheep carcasses

\begin{tabular}{|c|c|c|c|c|c|}
\hline \multicolumn{4}{|c|}{ Bovine carcass } & \multicolumn{2}{|c|}{ Sheep carcass } \\
\hline \multicolumn{2}{|c|}{ Forequarter } & \multicolumn{2}{|c|}{ Hindquarter } & Forequarter & Hindquarter \\
\hline \multirow{8}{*}{$\begin{array}{l}\text { Chuck } \\
\text { Brisket } \\
\text { Plate } \\
\text { Rib eye } \\
\text { Fore ribs } \\
\text { Chuck } \\
\text { roll }\end{array}$} & Shoulder & Top bit and & Striploin & Best end neck & Leg \\
\hline & Shoulder clod & rump & Tenderloin, & Shoulder & Chump \\
\hline & Blade & Top side, inside & fillet & Chop & Loin, chop \\
\hline & Chuck & round & Heel muscle & Flank & Saddle \\
\hline & tenderloin & $\begin{array}{l}\text { Nnuckie, } \\
\text { thick flank }\end{array}$ & Hindshank & Foreshank & Tenderloin \\
\hline & Foreshank & & Flank & Brisket & Hindshank \\
\hline & Brisket & Silverside & & & \\
\hline & & Top round & & & \\
\hline
\end{tabular}

\section{Conclusions}

Consumer behaviour regarding beef and lamb meat is difficult to assess accurately, due to the large variation, both among and within countries. There are several differences among European countries, concerning the preferred endogenous factors of beef and lamb. The puzzle gets more complicated when the various social, economic and cultural factors, and the contemporary events are considered. In addition, exogenous factors, such as the price of the product, seem to affect consumer behaviour both within countries and among them. Globally, two large consumer groups are recognised: the consumers that are willing to pay more for a better-quality food and the consumers that look for the cheapest food, regardless of quality. Different geographical areas within the same continent are quite diverse on their dietetic preferences, perhaps due to differences in traditional animal husbandry. Even is certain countries, like Greece, these differences can be profound, creating a quite different market landscape. However, some similarities are observed among countries. The vast majority of consumers prefer domestic beef and sheep. Similarly, consumers prefer to buy fresh meat, relying mostly on its bright red colour. Categorisation of consumers in groups with specific common characteristics, such as the categorisation of Ripoll et al. (2018) can help predict the reaction of consumers to certain 
stimuli. Adoption of similar categorisations is particularly important for meat producers and professionals, as it will enable the accurate promotion of products according to specific consumers' categories. Especially in countries such as Greece in which large differences occur between different districts, mapping of consumer preferences and trends towards meat is a prerequisite for the economic growth of this sector. In any case, it is necessary for the beef and lamb meat market to continuously assess the factors affecting consumer choices in order to adapt to any contemporary changes observed.

\section{Acknowledgements}

This research has been co-financed by the European Regional Development Fund of the European Union and Greek national funds through the Operational Program Competitiveness, Entrepreneurship and Innovation, under the call RESEARCH CREATE - INNOVATE (project code: T1EDK-05479).

\section{References}

Aboah, J. and Lees, N. (2020) 'Consumers use of quality cues for meat purchase: Research trends and future pathways', Meat Science, Vol. 166, p.108142 [online] https://doi.org /10.1016/j.meatsci.2020.108142.

Acebrón, L.B. and Dopico, D.C. (2000) 'The importance of intrinsic and extrinsic cues to expected and experienced quality: an empirical application for beef', Food Quality and Preference, Vol. 11, pp.229-238 [online] https://doi.org/10.1016/S0950-3293(99)00059-2.

Almli, V.L., van Wezemael, L., Verbeke, W. and Ueland, T. (2013) 'One technology does not fit all: profiling consumers of tender and tenderised beef steaks', Meat Science, Vol. 93, pp.361-370 [online] https://doi.org/10.1016/j.meatsci.2012.10.002.

Banović, M., Grunert, K.G., Barreira, M.M. and Fontes, M.A. (2009) 'Beef perception at the point of purchase: a study from Portugal', Food Quality and Preference, Vol. 20, pp.335-342 [online] https://doi.org/10.1016/j.foodqual.2009.02.009.

Bernabéu, R. and Tendero, A. (2005) 'Preference structure for lamb meat consumers. A Spanish case study', Meat Science, Vol. 71, pp.464-470 [online] https://doi.org/10.1016/ j.meatsci.2005.04.027.

Berndsen, M. and van der Pligt, J. (2005) 'Risks of meat: the relative impact of cognitive, affective and moral concerns', Appetite, Vol. 44, pp.195-205 [online] https://doi.org/10.1016/ j.appet.2004.10.003.

Bernués, A., Olaizola, A. and Corcoran, K. (2003) 'Labelling information demanded by European consumers and relationships with purchasing motives, quality and safety of meat', Meat Science, Vol. 65, pp.1095-1106 [online] https://doi.org/10.1016/S0309-1740(02)00327-3.

Bernués, A., Ripoll, G. and Panea, B. (2012) 'Consumer segmentation based on convenience orientation and attitudes towards quality attributes of lamb meat', Food Quality and Preferences, Vol. 26, pp.211-220 [online] https://doi.org/10.1016/j.foodqual.2012.04.008.

Bhatti, M.A., Godfrey, S.S., Ip, R.H.L., Gaarder, M.Ø., Aslam, S., Steinheim, G., Wynn, P., Hopkins, D.L., Horneland, R., Eik, L.O. and Ådnøy, T. (2021) 'An exploratory study of Muslim consumers' halal meat purchasing intentions in Norway', Acta Agriculturae Scandinavica A: Animal Sciences, Vol. 70, No. 1, pp.61-70 [online] https://doi.org/10.1080/ 09064702.2020 .1842488 .

Boito, B., Lisbinski, E., Campo, M.D.M., Guerrero, A., Resconi, V., de Oliveira, T.E. and Barcellos, J.O.J (2021) 'Perception of beef quality for Spanish and Brazilian consumers', Meat Science, Vol. 172, p.108312 [online] https://doi.org/10.1016/j.meatsci.2020.108312. 
Boutron-Ruault, M-C., Mesrine, S. and Pierre, F. (2017) 'Meat consumption and health outcomes', Vegetarian and Plant-Based Diets in Health and Disease Prevention, pp.197-214 [online] https://doi.org/10.1016/B978-0-12-803968-7.00012-5.

Bremner, H.A. (2000) 'Toward practical definitions of quality for food science', Critical Reviews in Food Science and Nutrition, Vol. 40, No. 1, pp.83-90 [online] https://doi.org/10.1080/ 10408690091189284.

Capuano, E., Boerrigter-Eenling, R., van der Veer, G. and van Ruth, S.M. (2013) 'Analytical authentication of organic products: an overview of markers', Journal of the Science of Food and Agriculture, Vol. 93, No. 1, pp.12-28 [online] https://doi.org/10.1002/jsfa.5914.

Carpenter, C.E., Cornforth, D.P. and Whittier, D. (2001) 'Consumer preferences for beef color and packaging did not affect eating satisfaction', Meat Science, Vol. 57, No. 4, pp.359-363 [online] https://doi.org/10.1016/S0309-1740(00)00111-X.

Chambers, S., Lobb, A., Butler, L., Harvey, K. and Traill, W.B. (2007) 'Local, national and imported foods: a qualitative study', Appetite, Vol. 49, pp.208-213 [online] https://doi.org/10.1016/j.appet.2007.02.003.

Cheah, I., Shimul, A.S., Liang, J. and Phau, I. (2020) 'Drivers and barriers toward reducing meat consumption', Appetite, Vol. 149 [online] https://doi.org/10.1016/j.appet.2020.104636.

Christodoulou, V., Bampidis, V.A., Sossidou, E. and Ambrosiadis, J. (2007) 'Evaluation of Florina (Pelagonia) sheep breed for growth and carcass traits', Small Ruminant Research, Vol. 70, pp.239-247 [online] https://doi.org/10.1016/j.smallrumres.2006.03.010.

Clonan, A., Wilson, P., Swift, J.A., Leibovici, D.G. and Holdsworth, M. (2015) 'Red and processed meat consumption and purchasing behaviours and attitudes: Impacts for human health, animal welfare and environmental sustainability', Public Health Nutrition, Vol. 18, No. 13, pp.2446-2456 [online] https://doi.org/10.1017/S1368980015000567.

De Jonge, J. and van Trijp, H.C.M. (2013) 'Meeting heterogeneity in consumer demand for animal welfare: a reflection on existing knowledge and implications for the meat sector', Journal of Agricultural and Environmental Ethics, Vol. 26, No. 3, pp.629-661 [online] https://doi.org/ 10.1007/s10806-012-9426-7.

Deliza, R. and MacFie, H.J.H. (1996) 'The generation of sensory expectations by external cues and its effect on sensory perception and hedonic ratings: a review', Journal of Sensory Studies, Vol. 11, pp.103-128 [online] https://doi.org/10.1111/j.1745-459X.1996.tb00036.x.

Dickinson, D.L. and Kakoschke, N. (2021) 'Seeking confirmation? biased information search and deliberation in the food domain', Food Quality and Preference, Vol. 91 [online] https://doi.org/10.1016/j.foodqual.2021.104189.

Dudinskaya, E.C., Naspetti, S., Arsenos, G., Caramelle-Holtz, E., Latvala, T., Martin-Collado, D., Orsini, S., Ozturk, E. and Zanoli, R. (2021) 'European consumers' willingness to pay for red meat labelling attributes', Animals, Vol. 11, No. 2, pp.1-16 [online] https://doi.org/ 10.3390/ani11020556.

Faber, I., Castellanos-Feijoó, N.A., Van de Sompel, L., Davydova, A. and Perez-Cueto, F.J.A. (2020) 'Attitudes and knowledge towards plant-based diets of young adults across four european countries. exploratory survey', Appetite, Vol. 145 [online] https://doi.org/ 10.1016/j.appet.2019.104498.

FAOSTAT (2021) Food Supply - Livestock and Fish Primary Equivalent [online] http://www.fao.org/faostat/en/\#data/CL (accessed 14 March 2021).

Feldmann, C. and Hamm, U. (2015) 'Consumers' perceptions and preferences for local food: a review', Food Quality and Preference, Vol. 40, No. PA, pp.152-164 [online] https://doi.org/10.1016/j.foodqual.2014.09.014.

Feuz, R., Norwood, F.B. and Ramanathan, R. (2020) 'Do consumers have an appetite for discolored beef?', Agribusiness, , Vol. 36, No. 4, pp.631-652 [online] https://doi.org/10.1002/agr.21651.

Font-i-Furnols, M. and Guerrero, L. (2014) 'Consumer preference, behavior and perception about meat and meat products: an overview', Meat Science, Vol. 98, pp.361-371 [online] https://doi.org/10.1016/j.meatsci.2014.06.025. 
Font-i-Furnols, M., Realini, C., Montossi, F., Sañudo, C., Campo, M.M., Oliver, M.A., Nute, G.R. and Guerrero, L. (2011) 'Consumer's purchasing intention for lamb meat affected by country of origin, feeding system and meat price: A conjoint study in Spain, France and United Kingdom', Food Quality and Preference, Vol. 22, pp.443-451 [online] https://doi.org/ 10.1016/j.foodqual.2011.02.007.

Garnier, J.P., Klont, R. and Plastow, G. (2003) 'The potential impact of current animal research on the meat industry and consumer attitudes towards meat', Meat Science, Vol. 63, pp.79-88 [online] https://doi.org/10.1016/S0309-1740(02)00059-1.

George, E.S., Sood S., Broughton, A., Cogan, G., Hickey, M. Chan, W.S., Sudan, S. and Nicoll, A.J. (2021) 'The association between diet and hepatocellular carcinoma: a systematic review', Nutrients, Vol. 13, No. 1, pp.1-23 [online] https://doi.org/10.3390/nu13010172.

Gracia, A. and De-Magistris, T. (2013) 'Preferences for lamb meat: a choice experiment for Spanish consumers', Meat Science, Vol. 95, pp.396-402 [online] https://doi.org/ 10.1016/j.meatsci.2013.05.006.

Grunert, K.G. (2006) 'Future trends and consumer lifestyles with regard to meat consumption', Meat Science, Vol. 74, pp.149-160 [online] https://doi.org/10.1016/j.meatsci.2006.04.016.

Grunert, K.G., Bredahl, L. and Brunso, K. (2004) 'Consumer perception of meat quality and implications for product development in the meat sector - a review', Meat Science, Vol. 66, pp.259-272 [online] https://doi.org/10.1016/S0309-1740(03)00130-X.

Guàrdia, M.D., Guerrero, L., Gelabert, J., Gou, P. and Arnau, J. (2006) 'Consumer attitude towards sodium reduction in meat products and acceptability of fermented sausages with reduced sodium content', Meat Science, Vol. 73, pp.484-490 [online] https://doi.org/10.1016/ j.meatsci.2006.01.009.

Guenther, P.M., Jensen, H.H., Batres-Marquez, S.P. and Chen, C. (2005) 'Sociodemographic, knowledge, and attitudinal factors related to meat consumption in the United States', Journal of the American Dietetic Association, Vol. 105, pp.1266-1274 [online] https://doi.org/ 10.1016/j.jada.2005.05.014.

Henchion, M.M., McCarthy, M. and Resconi, V.C. (2017) 'Beef quality attributes: a systematic review of consumer perspectives', Meat Science, Vol. 128, pp.1-7 [online] https://doi.org/ 10.1016/j.meatsci.2017.01.006.

Holm, L. and Møhl, M. (2000) 'The role of meat in everyday food culture: an analysis of an interview study in Copenhagen', Appetite, Vol. 34, pp.277-283 [online] https://doi.org/ 10.1006/appe.2000.0324.

Hossain, M.A.M., Uddin, S.M.K., Sultana, S., Wahab, Y.A., Sagadevan, S., Johan, M.R. and Ali, M.E. (2020) 'Authentication of Halal and Kosher meat and meat products: Analytical approaches, current progresses and future prospects', Critical Reviews in Food Science and Nutrition [online] https://doi.org/10.1080/10408398.2020.1814691.

Kim, R., Suwunnamek, O. and Toyoda, T. (2008) 'Consumer attitude towards organic labelling schemes in Japan', Journal of International Food \& Agribusiness Marketing, Vol. 20, pp.55-71 [online] https://doi.org/10.1080/08974430802157622.

Korat, A.V.A., Willett, W.C. and Hu, F.B. (2014) 'Diet, lifestyle, and genetic risk factors for type 2 diabetes: a review from the nurses' health study, nurses' health study 2 , and health professionals' follow-up study', Current Nutrition Reports, Vol. 3, No. 4, pp.345-354 [online] https://doi.org/10.1007/s13668-014-0103-5.

Koutsoumanis, K., Allende, A., Alvarez-Ordóñez, A., Bolton, D., Bover-Cid, S., Chemaly, M., Davies, R., De Cesare, A., Herman, L., Lindqvist, R., Nauta, M., Peixe, L., Ru, G., Simmons, M., Skandamis, P., Suffredini, E., Sánchez, J.Á., Blagojevic, B., Fürst, P., Garin-Bastuji, B., Jensen, H.E., Paulsen, P., Baert, K., Barrucci, F., Broglia, A., Georgiadis, M., Hempen, M. and Hilbert, F. (2020) 'Evaluation of public and animal health risks in case of a delayed post-mortem inspection in ungulates', EFSA Journal, Vol. 18, No. 12 [online] https://doi.org/10.2903/j.efsa.2020.6307. 
Krystallis, A. and Arvanitoyannis, I.S. (2006) 'Investigating the concept of meat quality from the consumers' perspective: the case of Greece', Meat Science, Vol. 72, pp.164-176 [online] https://doi.org/10.1016/j.meatsci.2005.06.013.

Krystallis, A., Arvanitoyannis, I. and Chryssohoidis, G. (2006) 'Is there a real difference between conventional and organic meat? Investigating consumers' attitudes towards both meat types as an indicator of organic meat's market potential', Journal of Food Products Marketing, Vol. 12, pp.47-78 [online] https://doi.org/10.1300/J038v12n02_04.

Kumar, Y. (2019) 'Development of Low-fat/reduced-fat processed meat products using fat replacers and analogues', Food Reviews International [online] https://oi.org/10.1080/ 87559129.2019.1704001.

Latvala, T., Niva, M., Mäkelä, J., Pouta, E., Heikkilä, J., Kotro, J. and Forsman-Hugg, S. (2012) 'Diversifying meat consumption patterns: consumers' self-reported past behavior and intentions for change', Meat Science, Vol. 92, pp.71-77 [online] https://doi.org/ 10.1016/j.meatsci.2012.04.014.

Leroy, F. and Praet, I. (2015) 'Meat traditions. the co-evolution of humans and meat', Appetite, Vol. 90, pp.200-211 [online] https://doi.org/10.1016/j.appet.2015.03.014.

López-Pedrouso, M., Lorenzo, J.M., Gullón, B., Campagnol, P.C.B. and Franco, D. (2021) 'Novel strategy for developing healthy meat products replacing saturated fat with oleogels', Current Opinion in Food Science, Vol. 40, pp.40-45 [online] https://doi.org/10.1016/ j.cofs.2020.06.003.

Mandolesi, S., Naspetti, S., Arsenos, G., Caramelle-Holtz, E., Latvala, T., Martin-Collado, D., Orsini, S., Ozturk, E. and Zanoli, R. (2020) 'Motivations and barriers for sheep and goat meat consumption in Europe: a means-end chain study', Animals, Vol. 10, No. 6, pp.1-16 [online] https://doi.org/10.3390/ani10061105.

Massaglia, S., Merlino, V.M. and Borra, D. (2018) 'Marketing strategies for animal welfare meat identification: comparison of preferences between millennial and conventional consumers', Quality-Access to Success, Vol. 19, No. S1, pp.305-311.

Matsuishi, M., Igeta, M., Takeda, S. and Okitani, A. (2004) 'Sensory factors contributing to the identification of the animal species of meat', Journal of Food Science, Vol. 69, pp.S218-S220 [online] https://doi.org/10.1111/j.1365-2621.2004.tb11008.x.

Maughan, T. and Martini, S. (2012) 'Identification and quantification of flavor attributes present in chicken, lamb, pork, beef and turkey', Journal of Food Science, Vol. 77, pp.S115-S121 [online] https://doi.org/10.1111/j.1750-3841.2011.02574.x.

McNeill, S. and van Elswyk, M.E. (2012) 'Red meat in global nutrition', Meat Science, Vol. 92, No. 3, pp.166-173 [online] https://doi.org/10.1016/j.meatsci.2012.03.014.

Merlino, V.M., Borra, D., Girgenti, V., Dal Vecchio, A. and Massaglia, S. (2018) 'Beef meat preferences of consumers from northwest Italy: analysis of choice attributes', Meat Science, Vol. 143, pp.119-128 [online] https://doi.org/10.1016/j.meatsci.2018.04.023.

Mesías, F.J., Escribano, M., De Ledesma, A.R. and Pulido, F. (2005) 'Consumers' preferences for beef in the Spanish region of Extremadura: a study using conjoint analysis', Journal of the Science of Food and Agriculture, Vol. 85, pp.2487-2494 [online] https://doi.org/10.1002/ jsfa.2283.

Meyerding, S.G.H., Gentz, M., Altmann, B. and Meier-Dinkel, L. (2018) 'Beef quality labels: a combination of sensory acceptance test, stated willingness to pay, and choice-based conjoint analysis', Appetite, Vol. 127, pp.324-333 [online] https://doi.org/10.1016/j.appet.2018.05.008.

Michel, F., Hartmann, C. and Siegrist, M. (2021) 'Consumers' associations, perceptions and acceptance of meat and plant-based meat alternatives', Food Quality and Preference, Vol. 87, p.104063 [online] https://doi.org/10.1016/j.foodqual.2020.104063.

Mijatovic-Vukas, J., Capling, L., Cheng, S., Stamatakis, E., Louie, J., Cheung, N.W., Markovic, T. et al. (2018) 'Associations of diet and physical activity with risk for gestational diabetes mellitus: a systematic review and meta-analysis', Nutrients, Vol. 10, No. 6 [online] https://doi.org/10.3390/nu10060698. 
Miller, R. (2020) 'Drivers of consumer liking for beef, pork, and lamb: a review', Foods, Vol. 9, No. 4 [online] https://doi.org/10.3390/foods9040428.

Moeller, S.J., Miller, R.K., Edwards, K.K., Zerby, H.N., Logan, K.E., Aldredge, T.L., Stahl, C.A., Boggess, M. and Box-Steffensmeier, J.M. (2010) 'Consumer perception of pork eating quality as affected by pork quality attributes and end-point cooked temperature', Meat Science, Vol. 84, pp.14-22 [online] https://doi.org/10.1016/j.meatsci.2009.06.023.

Morrison, J.A., Balcombe, K., Bailey, A., Klonaris, S. and Rapsomanikis, G. (2003) 'Expenditure on different categories of meat in Greece: the influence of changing tastes', Agricultural Economics, Vol. 28, pp.139-150 [online] https://doi.org/10.1016/S0169-5150(02)00103-2.

Ngapo, T.M. and Dransfield, E. (2006) 'British consumers preferred fatness levels in beef: surveys from 1955, 1982 and 2002', Food Quality and Preference, Vol. 17, pp.412-417 [online] https://doi.org/10.1016/j.foodqual.2005.05.006.

Ngapo, T.M., Martin, J-F. and Dransfield, E. (2007) 'International preferences for pork appearance: I. Consumer choices', Food Quality and Preference, Vol. 18, pp.26-36 [online] https://doi.org/10.1016/j.foodqual.2005.07.001.

Paglarini, C.D.S., V.A.S. Vidal, S. Martini, R.L. Cunha, and M.A.R. Pollonio. (2020) 'Protein-based hydrogelled emulsions and their application as fat replacers in meat products: a review', Critical Reviews in Food Science and Nutrition [online] https://doi.org/10.1080/ 10408398.2020.1825322.

Pannier, L., Gardner, G.E., Pearce, K.L., McDonagh, M., Ball, A.J., Jacob, R.H. and Pethick, D.W. (2014) 'Associations of sire estimated breeding values and objective meat quality measurements with sensory scores in Australian lamb', Meat Science, Vol. 96, pp.1076-1087 [online] https://doi.org/10.1016/j.meatsci.2013.07.037.

Pethick, D.W., Ball, A.J., Banks, R.G. and Hocquette, J.F. (2011) 'Current and future issues facing red meat quality in a competitive market and how to manage continuous improvement', Animal Production Science, Vol. 51, pp.13-18 [online] https://doi.org/10.1071/AN10041.

Pethick, D.W., Davidson, R., Hopkins, D.L., Jacob, R.H., D’Souza, D.N., Thompson, J.M. and Walker, P.J. (2005) 'The effect of dietary treatment on meat quality and on consumer perception of sheep meat eating quality', Australian Journal of Experimental Agriculture, Vol. 45, pp.517-524 [online] https://doi.org/10.1071/EA03255.

Petrescu, D.C., Vermeir, I. and Petrescu-Mag, R.M. (2020) 'Consumer understanding of food quality, healthiness, and environmental impact: a cross-national perspective', International Journal of Environmental Research and Public Health, Vol. 17, No. 1 [online] https://doi.org/10.3390/ijerph17010169.

Povey, R., Wellens, B. and Conner, M. (2001) 'Attitudes towards following meat, vegetarian and vegan diets: an examination of the role of ambivalence', Appetite, Vol. 37, pp.15-26 [online] https://doi.org/10.1006/appe.2001.0406.

Realini, C.E., Font i Furnols, M., Sañudo, C., Montossi, F., Oliver, M.A. and Guerrero, L. (2013) 'Spanish, French and British consumers' acceptability of Uruguayan beef, and consumers' beef choice associated with country of origin, finishing diet and meat price', Meat Science, Vol. 95, pp.14-21 [online] https://doi.org/10.1016/j.meatsci.2013.04.004.

Reicks, A.L., Brooks, J.C., Garmyn, A.J., Thompson, L.D., Lyford, C.L. and Miller, M.F. (2011) 'Demographics and beef preferences affect consumer motivation for purchasing fresh steaks and roasts', Meat Science, Vol. 87, pp.403-411 [online] https://doi.org/10.1016/ j.meatsci.2010.11.018.

Rezitis, A.N. and Stavropoulos, K.S. (2012) 'Greek meat supply response and price volatility in a rational expectations framework: a multivariate GARCH approach', European Review of Agricultural Economics, Vol. 39, pp.309-333 [online] https://doi.org/10.1093/erae/jbr038.

Ripoll, G., Joy, M. and Panea, B. (2018) 'Consumer perception of the quality of lamb and lamb confit', Foods, Vol. 7 [online] https://doi.org/10.3390/foods7050080. 
Sañudo, C., Alfonso, M., San Julián, R., Thorkelsson, G., Valdimarsdottir, T., Zygoyiannis, D., Stamataris, C., Piasentier, E., Mills, C., Berge, P., Dransfield, E., Nute, G.R., Enser, A.V. and Fisher, A.V. (2007) 'Regional variation in the hedonic evaluation of lamb meat from diverse production systems by consumers in six European countries', Meat Science, Vol. 75, pp.610-621 [online] https://doi.org/10.1016/j.meatsci.2006.09.009.

Scozzafava, G., Corsi, A.M., Casini, L., Contini, C. and Loose, S.M. (2016) 'Using the animal to the last bit: consumer preferences for different beef cuts', Appetite, Vol. 96, pp.70-79 [online] https://doi.org/10.1016/j.appet.2015.09.004.

Silvestri, C., Aquilani, B., Piccarozzi, M. and Ruggieri, A. (2020) 'Beef traditional food: consumer before purchase preferences based on quality', Italian Journal of Food Science, Vol. 32, No. 1, pp.16-44 [online] https://doi.org/10.14674/IJFS-1403.

Skapetas, B., Sinapis, E., Hatziminaouglou, J., Karalazos, A. and Katanos, J. (2006) 'Effect of age at slaughter on carcass characteristics and carcass composition in lambs of mountain Greek breeds', Czech Journal of Animal Science, Vol. 51, pp.311-317 [online] https://doi.org/10.17221/3944-cjas.

Stampa, E., Schipmann-Schwarze, C. and Hamm, U. (2020) 'Consumer perceptions, preferences, and behavior regarding pasture-raised livestock products: a review', Food Quality and Preference, Vol. 82 [online] https://doi.org/10.1016/j.foodqual.2020.103872.

Toi, P.L., Anothaisintawee, T., Chaikledkaew, U., Briones, J.R., Reutrakul, S. and Thakkinstian, A. (2020) 'Preventive role of diet interventions and dietary factors in type 2 diabetes mellitus: an umbrella review', Nutrients, Vol. 12, No. 9, pp.1-17 [online] https://doi.org/10.3390/ nu12092722.

Troy, D.J. and Kerry, J.P. (2010) 'Consumer perception and the role of science in meat industry', Meat Science, Vol. 86, pp.214-226 [online] https://doi.org/10.1111/1541-4337.12721.

Van Rijswijk, W. and Frewer, L.J. (2008) 'Consumer perceptions of food quality and safety and their relation to traceability', British Food Journal, Vol. 110, No. 10, pp.1034-1046 [online] https://doi.org/10.1108/00070700810906642.

Van Wezemael, L., Caputo, V., Nayga, R.M., Chryssochoidis, G. and Verbeke, W. (2014) 'European consumer preferences for beef with nutrition and health claims: A multi-country investigation using discrete choice experiments', Food Policy, Vol. 44, pp.167-176 [online] https://doi.org/10.1016/j.foodpol.2013.11.006.

Verbeke, J. and Ward, R.W. (2006) 'Consumer interest in information cues denoting quality traceability and origin: An application of ordered probit models to beef labels', Food Quality and Preference, Vol. 17, pp.453-467 [online] https://doi.org/10.1016/j.foodqual.2005.05.010.

Verbeke, W., Pérez-Cueto, F.J.A., de Barcellos, M.D., Krystallis, A. and Grunert, K.G. (2010) 'European citizen and consumer attitudes and preferences regarding beef and pork', Meat Science, Vol. 84, pp.284-292 [online] https://doi.org/10.1016/j.meatsci.2009.05.001.

Verbeke, W., Rutsaert, P., Bonne, K. and Vermeir, I. (2013) 'Credence quality coordination and consumers' willingness-to-pay for certified halal labelled meat', Meat Science, Vol. 95, pp.790-797 [online] https://doi.org/10.1016/j.meatsci.2013.04.042.

Vernia, F., Longo, S., Stefanelli, G., Viscido, A. and Latella, G. (2021) 'Dietary factors modulating colorectal carcinogenesis', Nutrients, Vol. 13, No. 1, pp.1-13 [online] https://doi.org/10.3390/ nu13010143.

Yang, L., Arnold, N.L., Drape, T., Williams, R.C., Archibald, T., Chapman, B. and Boyer, R. (2021) 'A survey of United States consumer awareness, purchasing, and handling of mechanically tenderized beef products', Food Control, Vol. 120, p.107505 [online] https://doi.org/10.1016/j.foodcont.2020.107505.

Zeng, L., Ruan, M., Liu, J., Wilde, P., Naumova, E.N., Mozaffarian, D. and Zhang, F.F. (2019) 'Trends in processed meat, unprocessed red meat, poultry, and fish consumption in the united states, 1999-2016', Journal of the Academy of Nutrition and Dietetics, Vol. 119, No. 7, pp.1085-1098 [online] https://doi.org/10.1016/j.jand.2019.04.004. 